\title{
NON-AGENDA
}

With the view of causing an increase to take place in the mass of national wealth, or with a view to increase of the means either of subsistence or enjoyment, without some special reason, the general rule is, that nothing ought to be done or attempted by government. The motto, or watchword of government, on these occasions, ought to be - Be quiet. . . Whatever measures, therefore, cannot be justified as exceptions to that rule, may be considered as non-agenda on the part of government.

\section{Saving Australia's Parrots from the Export Ban}

\author{
Brendan Moyle
}

$\mathrm{T}$ THE international market for wildlife and wildlife products is large in scope and size. One important part of this market originates in Australasia. Australian wildlife is both distinctive and highly sought after; and, as few countries have similar ecological characteristics to Australia's, foreign breeders find it difficult to rear successfully many Australian species. New Zealand is a notable exception, with several difficult Australian species being captive-bred (Antram \& Salisbury, 1991).

However, Australian residents are prohibited from engaging in this trade. The export of Australian parrots is effectively banned under the Wildlife Protection (Regulation of Exports and Imports) Act 1982. The few exceptions, involving household pets and scientific exchanges, are insufficient to meet the large overseas demand (Kingwell, 1993).

The ban ensures that foreign demand for Australian parrots is high relative to the legal supply. This is reflected in the price differentials between the domestic and foreign markets (see Table 1).

The rationale for the ban includes (but is not restricted to) conservation concerns: the export of specimens from endangered species is thought to increase the risk of extinction. But not all parrots that are in high demand overseas have an endangered status. The galah, for example, which is so abundant that it is regarded as an agricultural pest in some States, typically fetches relatively high prices in Europe and North America. Indeed, the species that make up the bulk of the international 
trade are not recognised as endangered (Moyle, 1995). Moreover, a large and legal domestic market exists for Australian wildlife. So if trade is supposed to be detrimental to a species' chances of survival, the ban on exports alone is likely to be ineffective.

\section{Table 1}

\section{Average prices in selected countries for four Australian species of parrot: AS per pair, 1993}

\begin{tabular}{|lcccc|}
\hline \multicolumn{1}{c}{ Species } & Australla & USA & Italy & Germany \\
\hline Red-tailed black & 4,000 & - & 12,550 & - \\
cockatoo & & & & \\
Galah & 50 & 4,450 & 3,000 & 1,500 \\
Major Mitchell & 850 & 11,000 & 7,500 & \\
Gang Gang & 1,300 & 18,500 & 5,015 & 28,175 \\
\hline
\end{tabular}

Source: TRAFFIC Oceania, Sydney.

\section{Why the Ban is Difficult to Enforce}

It is extremely unlikely that the illegal export of parrots can be reduced by enforcement policy alone.

The Australasian area offers some distinctive advantages for smugglers. One is the Australian domestic market, which makes procurement of stock relatively easy; in a recent case the smugglers simply obtained their stock from a number of pet shops (Ansley, 1995): A second advantage is the abundant supply of some species in the wild. A third is the ease with which birds can be exported from New Zealand. Since New Zealand shares many ecological characteristics with Australia, New Zealand breeders can easily rear Australian parrots for the North American and European markets. In fact, New Zealand aviculturists provide the majority of internationally traded specimens of certain species (see Table 2). The legitimate trade in effect conceals the illegal trade, whether the smuggled specimens are intended for New Zealand customers or for re-export to overseas markets. Indeed, conditions are so favourable that wild populations of some Australian parrots, such as crimson rosellas and sulphur-crested cockatoos, have colonised New Zealand rainforest (Antram \& Salisbury, 1991).

New Zealand and the United States put little effort into detecting laundered animals, since the activity is both costly and has a very low success rate. It is very difficult to prove that a specimen has an illegal origin once it has entered the aviary system. As a result, CITES export permits of Australian parrots from New Zealand can be obtained with little scrutiny from the authorising body. Antram and Salisbury (1991) report that in many cases the exporter has merely had to sign an affidavit attesting to the 'legal' origin of the specimens. A further difficulty is that partici- 
pants in the illegal wildlife trade, unlike participants in other illegal markets such as the drug trade, can easily conceal themselves among the legal participants of the trade.

\section{Table 2}

\section{Total international and New Zealand commercial exports of three species of parrot: gross numbers, 1989-94}

\begin{tabular}{|cccccccc|}
\hline Year & Najor Mitchell & & Galah & & Gang Gang \\
\hline & Total & NZ & Total & NZ & Total & NZ \\
\hline 1989 & 23 & 14 & 82 & 15 & 10 & 10 \\
1990 & 42 & 14 & 330 & 198 & 18 & 10 \\
1991 & 42 & 20 & 275 & 191 & 2 & 2 \\
1992 & 51 & 26 & 166 & 75 & 1 & 0 \\
1993 & 101 & 92 & 315 & 226 & 1 & 1 \\
1994 & 78 & 53 & 200 & 107 & 8 & 3 \\
\hline
\end{tabular}

Source: World Conservation Monitoring Centre, Cambridge.

The dispersed nature of the market makes the market very reliant on the reputation of breeders, so that breeders with reputations for honesty can use this as cover for illegal activity. Law-enforcement agencies thus cannot rely on a high rate of tip-offs from suspicious honest breeders.

Border protection is also rather imperfect in relation to wildlife smuggling. Small aircraft can be used to fly stock out of Australia. Both Australia and New Zealand have a large number of unsupervised airfields as a result of their agricultural economies, enabling smugglers to avoid scrutiny entirely. Northern Australia has approximately 3,000 airfields suitable for smuggling (Halstead, 1992). Only one intercept of a light plane has occurred in New Zealand; most intercepts are of bodypacks or egg-vests on couriers.

Fines for illegal activity are typically low. In 1992 the largest fine that had been applied in Australia was $\$ 7,200$ (Halstead, 1992). In New Zealand, authorities have declined to prosecute a smuggler on at least one occasion.

\section{The Costs of the Export Ban}

Australia's export ban on parrots has a number of costs. As well as the forgone opportunities for Australian breeders to derive additional revenue from higher international prices, economic costs include those associated with attempting to enforce the trade ban. Prosecution costs are typically larger than the fines exacted. As eggs are now the most popular way to transport parrots, hatching them is necessary for identification for prosecution purposes. In a recent case in Australia, this cost $\$ 25,000$ (Halstead, 1992). This was in addition to the other costs associated with prosecuting offenders. 
But there are conservation costs as well. First, the ban shifts the laundering point of Australia's parrots to its neighbours. This means that Australian parrots enter, say, New Zealand without going through a quarantine process. This in turn increases the risk of parrot diseases spreading among New Zealand's native parrot species. As all New Zealand parrots and almost all New Zealand parakeets are recognised as endangered, the appearance of a new parrot disease could be catastrophic.

A second conservation cost of the ban is that it encourages excessive taking from the wild. The survival rate of smuggled wildlife is generally low (Wildlife Conservation International, 1992). Smugglers must take a large stock from the wild to ensure that enough survivors reach their destination. For rare and valued species this too has a conservation cost as populations become depleted.

\section{Effects of Lifting the Ban}

One of the goals of the current trade ban is to prevent rare species being exported from Australia at an unsustainable rate. But it is not obvious that lifting the export ban would result in a greater traffic of rare species; quite possibly, fewer rare species would be exported, since legal exports may depress prices.

The problem of taking wild birds for export could be overcome by allowing only captive-bred species to be exported. In fact, reputable overseas aviaries prefer captive-bred specimens as they are more familiar with humans and are likely to be healthier than wild ones.

However, a possible problem could remain with laundered animals. Some form of legal export trade would make it worthwhile for the criminally-inclined to launder their wild stock in Australian rather than New Zealand aviaries, thus reducing the risk of an exotic disease infecting native New Zealand parrots. However, some breeders could attempt to introduce eggs collected in the wild into their aviaries, whose offspring could then be passed off as having been bred within that aviary. (This in fact is one of the rationales for the export ban.) The problem here is that it is difficult to verify the origins of parrots. Yet other consumer goods have properties that are difficult to verify, such as reliability and durability. In such cases market mechanisms, like guarantees and brand names, have evolved to assure the customer that the goods have the properties claimed by producers. Corresponding mechanisms could evolve in a wildlife market. For instance, breeders may be able to establish a reputation for dealing only in legitimate animals by inviting independent experts to inspect their facilities regularly and without warning; and export permits could be revoked if laundered stock were detected. Such detection is becoming easier with the advent of DNA technology. The use of DNA testing is a very strong deterrent, as it can detect laundering well after the event.

Laundered animals can also be detected through the breeding success rates of rare species. A breeder that is supplementing his stock with specimens collected illegally will have a higher success rate than his honest competitors. This success rate is a signal to law-enforcement agencies (and the breeder's competitors) that poaching or smuggling may have occurred. 
Breeders may find it advantageous to make use of DNA technology to prove the lineage of their species. This would also reassure customers about the breeder's credentials. However, while DNA technology is making laundering more difficult, it is the most expensive available method for establishing the origin of a species; and, with low domestic prices, there is little incentive for Australian breeders to bear the costs of this procedure. This is a standard property-rights problem: low prices lower the incentive to care for and defend an interest in the property. Conversely, the higher prices that could be obtained in the international market would increase the willingness of breeders to bear the cost of DNA typing. Less reliable, but cheaper, methods of establishing secure private property rights to parrots include the use of robust leg bands or implanted microchips.

The final advantage of opening up export trade in Australian parrots is the likely supply-side response by breeders. The fact that the skills of New Zealand aviculturists have surpassed those of Australian breeders (Antram \& Salisbury, 1991) suggests that the New Zealand breeders have had a greater incentive to improve those skills: they can take advantage of higher international prices. Australian breeders would face the same incentive to improve their skills if they could obtain international prices for their stock.

\section{Concluding Remarks}

The trade ban nurtures and supports an illegal traffic of parrots that authorities cannot stamp out. This traffic compromises the status of parrot species in New Zealand and encourages illegal takings from the wild in Australia. A preference for the illusion of certainty offered by the legislation stifles the opportunity to develop private-sector solutions.

Deterring the illegal traffic is made difficult by the small fines imposed by Australian and New Zealand courts. However, while smuggling networks utilise couriers who have low wealth or income, it is impossible to set fines at a level that deters. As a result, the illegal market in Australian parrots cannot be suppressed by lawenforcement agencies.

The economic costs of the ban include the lost export opportunities to Australian aviculturists and the costs of law enforcement. But it is not obvious that these costs are offset by desirable conservation outcomes. As the illegal traffic cannot be prevented under the current legislative framework, the current ban on the export of parrots should be reconsidered.

Should an export trade in parrots be permitted, exporters would have sufficient incentive to take steps to prove that their stock is aviary-bred. If collecting from the wild is permitted, for instance by a ranching approach, then exporters would take steps to prove that their stock is not from threatened populations. 


\section{Non-Agenda}

\section{References}

Ansley, B. (1995), 'Smugglers in Paradise', Listener, 28 October: 18-21.

Antram, F. \& R. Salisbury (1991), International Trade in Australian Parrots, Australian National Parks and Wildife Service, Canberra.

Halstead, B. (1992), Traffic in Flora and Fauna, Australian Institute of Criminology, Canberra (Trends and Issues in Crime and Criminal Justice, No. 41).

Jupp, T. (1996), 'Carnaby's Cockatoo: Preventing a Crisis', Psittascene 8(2): 8-9.

Kingwell, R. (1993), 'Australian Native Birds: Is Export Prohibition the Best Policy', paper delivered to a conference of the Australian Agricultural Fconomics Society, Sydney (February).

Moyle, B. (1995), 'How Much Is That Galah In The Window?', Department of Fconomics Seminar, Waikato University, Hamilton.

Wildlife Conservation International (1992), The Wild Bird Trade: When a Bird in the Hand Means None in the Bush, New York Zoological Society, New York. 